\title{
Discrepancies in general surgery medical terminology between South and North Korea
}

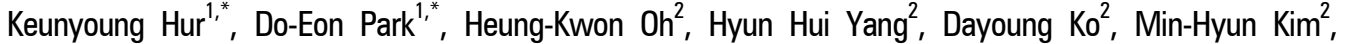 \\ Myung Jo Kim², Sung II Kang ${ }^{2}$, Duck-Woo Kim² and Sung-Bum Kang ${ }^{2}$ \\ ${ }^{1}$ Seoul National University College of Medicine, Seoul and ${ }^{2}$ Department of Surgery, Seoul National University \\ Bundang Hospital, Seongnam, Korea
}

Purpose: The purpose of this study was to categorize surgery-related medical terminologies used in South and North Korea and to compare and analyze discrepancies observed in the terms.

Methods: This study collected medical terminology used in the North Korean medical book "Surgery" and compared it to medical terminology found in the medical glossary of South Korea. The order of the subtitle was described according to the Instruction to Authors.

Results: In total, there were 2,168 individual medical terms, of which only 1,004 words (46.3\%) were identical to South Korean medical terms. There were 581 similar terms (26.8\%), 265 different terms (12.2\%), and 318 terms that are nonexistent in South Korea (14.7\%).

Conclusion: Less than half of the medical terms used in North Korea match those used in South Korea. It is expected that the prolongation of the current division of South and North Korea will only worsen this discrepancy. Further efforts to bridge the gap through academic exchange between South Korea and North Korea are required in preparation for an era of reunification.

Key Words: Republic of Korea, Democratic People's Republic of Korea, Medical terminology, Discrepancy.

\section{Introduction}

Medical terminology is a type of technical terminology that is an indispensable tool for appropriate communication in the field of medicine. As medicine itself has become more segmented and specialized, medical terminology has correspondingly become much more specialized [1]. Commonly used medical terms today mainly originate from loanwords. Many of the countries in the East Asian cultural sphere, including
Korea, are striving to establish their own unique or improved medical terminology; this is done through a process of trial and error. This is happening in each of the countries in a unique way, and an analysis of such processes can suggest a reasonable path forward.

In the case of South Korea and North Korea, medical terminologies started to diverge because of the division into two distinct sociopolitical systems, education systems, and differences in academic exchange with foreign countries [2]. The discrepancy in the medical terminologies of the two Koreas is only expected to grow
Received: November 8, 2017 • Revised: November 8, 2017 • Accepted: December 5, 2017 Corresponding Author: Heung-Kwon Oh (https://orcid.org/0000-0002-8066-2367) Department of Surgery, Seoul National University Bundang Hospital, 82 Gumi-ro 173beon-gil, Bundang-gu, Seongnam 13620, Korea

Tel: +82.31.787.7105 Fax:+82.31.787.4078 email: crsohk@gmail.com

*These authors contributed equally to this work.
Korean J Med Educ 2018 Mar; 30(1): 51-56. https://doi.org/10.3946/kjme.2018.81 eISSN: 2005-7288

(C) The Korean Society of Medical Education. All rights reserved. This is an open-access article distributed under the terms of the Creative Commons Attribution Non-Commercial License (http:// creativecommons.org/licenses/by-nc/3.0/), which permits unrestricted non-commercial use, distribution, and reproduction in any medium, provided the original work is properly cited. 
further as long as this division of South Korea and North Korea continues. It is easily foreseeable that establishing a suitable system of medical terminology for an era of a reunified Korea will be more difficult if the differences continue to increase. In addition, it is highly likely that the absence of a suitable medical terminology system will hinder the further development of medicine. Despite these clearly expected future difficulties, there are only a few studies that have investigated the medical terminologies of both Koreas, and existing studies are limited to an extremely small number of areas such as anesthesiology and parasitology [3,4].

In this context, this study aims to organize the medical terminologies found in surgery textbooks used in South and North Korea in order to analyze the degree of discrepancy. Further, the study offers a brief suggestion of the direction required to establish a suitable system of medical terminology, based on our analysis, in preparation for the reunification era.

\section{Methods}

This study collected North Korean medical terms from the book "Surgery", which is available in North Korea at the Information Center of the National Library of Korea, and compared them with medical terminology from the medical glossary of the Korean Medical Association in South Korea [5-7].

The North Korean textbook on surgery consists of an introduction and specialized sections. Terms were collected from all 21 chapters of the introduction and the 12 chapters related to surgery among the 23 chapters on specialized subjects. The subjects were recategorized into "breast and endocrine system," "vascular surgery," "peritoneum and hernia," "upper gastrointestinal tract," "hepatobiliary and pancreas," "coloproctology," and "pediatric surgery."

All the terms were categorized into "anatomy and pathophysiology"; "diagnosis"; "symptoms, physical examination, and general medical terminology"; "drugs"; "examination"; "treatment"; and "others." The degree of discrepancy was categorized into "identical terms," "similar terms with a difference of one or two syllables," "terms different from their South Korean counterparts," and "terms that are nonexistent or not used in South Korea." The categorization of terms and the difference in degree were conducted independently by two different researchers. When results differed, the authors arrived at a decision through discussion and agreement.

\section{Results}

Among the 2,821 terms collected in total, 653 were repeated terms, leaving a total of 2,168 individual terms. Only 1,004 were identical to South Korean terms, accounting for $46.3 \%$ of the total. Of the terms collected, 581 similar terms (26.8\%), 265 different terms (12.2\%), and 318 nonexistent terms (14.7\%), respectively, were found. A total of 678 and 2,143 terms were collected from the introduction and specialized subjects, respectively, and the ratio of the identical terms was similar for each section, accounting for $51.8 \%$ and $48.8 \%$, respectively. The ratio of nonexistent South Korean terms was $4.6 \%$ and $14.6 \%$, respectively, showing the highest discrepancy (Fig. 1). The examples of representative terms categorized according to discrepancy are shown in Table 1.

Of the 678 terms collected from the introduction, 229 terms for diagnosis (33.8\%) were found, followed by 205 terms for symptoms, physical examination, and general medical terminology (30.2\%); 101 terms for anatomy and pathophysiology (14.9\%); 50 for drugs (7.4\%); 34 for 
Fig. 1. Degree of Discrepancy in General Surgery Medical Terminology between South and North Korea

A

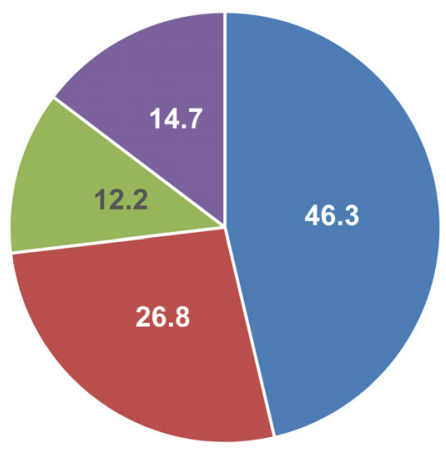

B

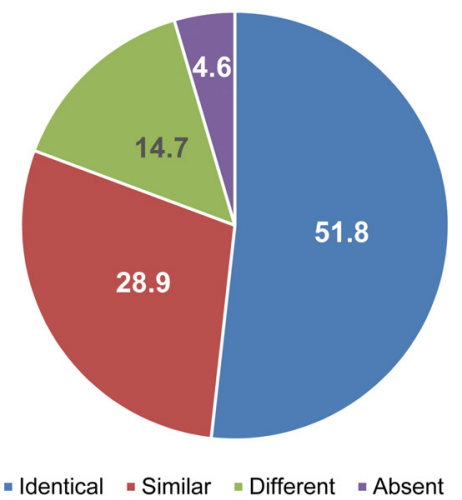

C

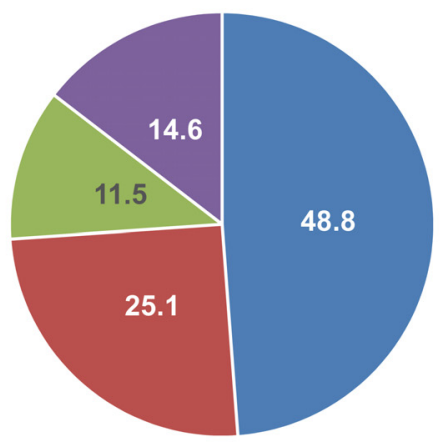

(A) Total. (B) Introduction section. (C) Specialized section. Data are presented as \%.

\begin{tabular}{|c|c|c|c|c|c|c|c|}
\hline \multicolumn{2}{|c|}{ Identical } & \multicolumn{2}{|c|}{ Similar } & \multicolumn{2}{|c|}{ Different } & \multicolumn{2}{|l|}{ Absent } \\
\hline NT & ST & NT & ST & NT & ST & NT & ST \\
\hline $\begin{array}{l}\text { 고혈압 } \\
\text { Hypertension }\end{array}$ & $\begin{array}{l}\text { 고혈압 } \\
\text { Hypertension }\end{array}$ & $\begin{array}{l}\text { 계실 } \\
\text { Diverticulum }\end{array}$ & $\begin{array}{l}\text { 게실 } \\
\text { Diverticulum }\end{array}$ & $\begin{array}{l}\text { 게우기 } \\
\text { Nausea }\end{array}$ & $\begin{array}{l}\text { 구역 } \\
\text { Nausea }\end{array}$ & $\begin{array}{l}\text { 고타통 } \\
\text { Gotatong }\end{array}$ & - \\
\hline $\begin{array}{l}\text { 결찰 } \\
\text { Ligation }\end{array}$ & $\begin{array}{l}\text { 결찰 } \\
\text { Ligation }\end{array}$ & $\begin{array}{l}\text { 륵막 } \\
\text { Pleura }\end{array}$ & $\begin{array}{l}\text { 늑막 } \\
\text { Pleura }\end{array}$ & $\begin{array}{l}\text { 동공커지기 } \\
\text { Mydriasis }\end{array}$ & $\begin{array}{l}\text { 산동 } \\
\text { Mydriasis }\end{array}$ & $\begin{array}{l}\text { 닛쉐 } \\
\text { Nisshe }\end{array}$ & - \\
\hline $\begin{array}{l}\text { 복강경 } \\
\text { Laparoscopy }\end{array}$ & $\begin{array}{l}\text { 복강경 } \\
\text { Laparoscopy }\end{array}$ & $\begin{array}{l}\text { 림파구 } \\
\text { Lymphocyte }\end{array}$ & $\begin{array}{l}\text { 림프구 } \\
\text { Lymphocyte }\end{array}$ & $\begin{array}{l}\text { 머리아픔 } \\
\text { Headache }\end{array}$ & $\begin{array}{l}\text { 두통 } \\
\text { Headache }\end{array}$ & $\begin{array}{l}\text { 드레나제창 } \\
\text { Drenajechang }\end{array}$ & - \\
\hline $\begin{array}{l}\text { 빈혈 } \\
\text { Anemia }\end{array}$ & $\begin{array}{l}\text { 빈혈 } \\
\text { Anemia }\end{array}$ & $\begin{array}{l}\text { 병조 } \\
\text { Lesion }\end{array}$ & $\begin{array}{l}\text { 병소 } \\
\text { Lesion }\end{array}$ & $\begin{array}{l}\text { 밥맛일기 } \\
\text { Anorexia }\end{array}$ & $\begin{array}{l}\text { 식욕부진 } \\
\text { Anorexia }\end{array}$ & $\begin{array}{l}\text { 약천방색 } \\
\text { Yakcheonbangsaek }\end{array}$ & - \\
\hline $\begin{array}{l}\text { 압통 } \\
\text { Tenderness }\end{array}$ & $\begin{array}{l}\text { 압통 } \\
\text { Tenderness }\end{array}$ & $\begin{array}{l}\text { 봉과직염 } \\
\text { Cellulitis }\end{array}$ & $\begin{array}{l}\text { 봉와직염 } \\
\text { Cellulitis }\end{array}$ & $\begin{array}{l}\text { 산소부족증 } \\
\text { Hypoxia }\end{array}$ & $\begin{array}{l}\text { 저산소증 } \\
\text { Hypoxia }\end{array}$ & $\begin{array}{l}\text { 열물산 } \\
\text { Yeolmulsan }\end{array}$ & - \\
\hline $\begin{array}{l}\text { 요골동맥 } \\
\text { Radial artery }\end{array}$ & $\begin{array}{l}\text { 요골동맥 } \\
\text { Radial artery }\end{array}$ & $\begin{array}{l}\text { 시구하부 } \\
\text { Hypothalamus }\end{array}$ & $\begin{array}{l}\text { 시상하부 } \\
\text { Hypothalamus }\end{array}$ & $\begin{array}{l}\text { 신상선 } \\
\text { Adrenal gland }\end{array}$ & $\begin{array}{l}\text { 부신 } \\
\text { Adrenal gland }\end{array}$ & $\begin{array}{l}\text { 존데검사 } \\
\text { Jondegeomsa }\end{array}$ & - \\
\hline $\begin{array}{l}\text { 위루 } \\
\text { Gastrostomy }\end{array}$ & $\begin{array}{l}\text { 위루 } \\
\text { Gastrostomy }\end{array}$ & $\begin{array}{l}\text { 복부앙기나 } \\
\text { Abdominal angina }\end{array}$ & $\begin{array}{l}\text { 복부앤지나 } \\
\text { Abdominal angina }\end{array}$ & $\begin{array}{l}\text { 오줌내기약 } \\
\text { diuretic }\end{array}$ & $\begin{array}{l}\text { 이뇨제 } \\
\text { diuretic }\end{array}$ & $\begin{array}{l}\text { 칠보환 } \\
\text { Chilbohwan }\end{array}$ & - \\
\hline $\begin{array}{l}\text { 크론병 } \\
\text { Crohn's disease }\end{array}$ & $\begin{array}{l}\text { 크론병 } \\
\text { Crohn's disease }\end{array}$ & $\begin{array}{l}\text { 페염 } \\
\text { Pneumonia }\end{array}$ & $\begin{array}{l}\text { 폐렴 } \\
\text { Pneumonia }\end{array}$ & $\begin{array}{l}\text { 오줌잦기 } \\
\text { Urinary frequency }\end{array}$ & $\begin{array}{l}\text { 빈뇨 } \\
\text { Urinary frequency }\end{array}$ & $\begin{array}{l}\text { 카플링궤양 } \\
\text { Coupling ulcer }\end{array}$ & - \\
\hline $\begin{array}{l}\text { 패혈증 } \\
\text { Sepsis }\end{array}$ & $\begin{array}{l}\text { 패혈증 } \\
\text { Sepsis }\end{array}$ & $\begin{array}{l}\text { 호흡곤난 } \\
\text { Dyspnea }\end{array}$ & $\begin{array}{l}\text { 호흡곤란 } \\
\text { Dyspnea }\end{array}$ & $\begin{array}{l}\text { 장불통증 } \\
\text { lleus }\end{array}$ & $\begin{array}{l}\text { 장폐색증 } \\
\text { lleus }\end{array}$ & $\begin{array}{l}\text { 킬리안삼각 } \\
\text { Kiliansamgak }\end{array}$ & - \\
\hline $\begin{array}{l}\text { 흉골 } \\
\text { Sternum }\end{array}$ & $\begin{array}{l}\text { 흉골 } \\
\text { Sternum }\end{array}$ & $\begin{array}{l}\text { 홍문 } \\
\text { Anus }\end{array}$ & $\begin{array}{l}\text { 항문 } \\
\text { Anus }\end{array}$ & $\begin{array}{l}\text { 피가래 } \\
\text { Hemoptysis }\end{array}$ & $\begin{array}{l}\text { 객혈 } \\
\text { Hemoptysis }\end{array}$ & $\begin{array}{l}\text { 횡단고 } \\
\text { Hoengdango }\end{array}$ & - \\
\hline
\end{tabular}

NT: North Korea terminology, ST: South Korea terminology.

treatment $(5.0 \%) ; 28$ for examination $(4.1 \%)$; and 31 for others (4.6\%). Of these, identical terms for diagnosis and examination accounted for $60.7 \%$, being the most similar, and drug terminology showed the highest discrepancy rate at $6 \%$ for nonexistent South Korean terms (except for the "others" category, at 12.9\%).

Of the 2,143 terms, including repeated terms collected from specialized subjects, terms for anatomy and patho- physiology appeared most often, with 673 terms (31.4\%), followed by 442 terms for symptoms, physical examination, and general medical terminology (20.7\%); 420 for diagnosis (19.6\%); 256 for treatment (11.9\%); 136 for drugs $(6.3 \%)$; 116 for examination $(5.4 \%)$; and 100 others (4.7\%). Of these, anatomy and pathophysiology had the greatest percentage of identical terms at $64.6 \%$, and treatment demonstrated the highest ratio (32.4\%) for 


\begin{tabular}{lccccccc}
\hline Table 2. Discrepancy in the Specialized Section \\
\cline { 2 - 8 } \multicolumn{1}{c}{ Variable } & $\begin{array}{l}\text { Anatomy, } \\
\text { pathology, } \\
\text { physiology }\end{array}$ & Diagnosis & $\begin{array}{c}\text { Symptoms, physical } \\
\text { examination, basic } \\
\text { medical terminology }\end{array}$ & Drug & Test & Treatment & Others \\
\hline Degree of discrepancy & & & & & & & \\
Identical & $435(64.6)$ & $219(52.1)$ & $191(43.2)$ & $41(30.1)$ & $56(48.3)$ & $89(34.8)$ & $15(15.0)$ \\
Similar & $122(18.1)$ & $136(32.4)$ & $159(36.0)$ & $39(28.7)$ & $28(24.1)$ & $50(19.5)$ & $4(4.0)$ \\
Different & $51(7.6)$ & $44(10.5)$ & $63(14.2)$ & $29(21.3)$ & $22(19.0)$ & $34(13.3)$ & $4(4.0)$ \\
Absent & $65(9.7)$ & $21(5.0)$ & $29(6.6)$ & $27(19.9)$ & $10(8.6)$ & $83(32.4)$ & $77(77.0)$ \\
Total & 673 & 420 & 442 & 136 & 116 & 256 & 100 \\
\hline
\end{tabular}

Data are presented as number $(\%)$.

nonexistent South Korean terms showing the greatest discrepancy (except for the "others" category, at 77.0\%) (Table 2).

The specialized subjects were recategorized into "breast and endocrine system," "vascular surgery," "peritoneum and hernia," "upper gastrointestinal tract," "hepatobiliary and pancreas," "coloproctology," and "pediatric surgery." Of these, pediatric surgery had the highest volume of identical terms at 54.9\% and peritoneum and hernia had the highest ratio of nonexistent South Korean terms at 19.5\%.

\section{Discussion}

This study is highly valuable because it is the first study that compares and analyzes the general medical terminology related to surgery that is used in South Korea and North Korea. So far, only two studies have compared the medical terminology of the two Koreasone that compared South Korean and North Korean terminologies for parasitology published in 1995 and another that compared the terminologies for anesthesiology [3,4]. However, both papers compared only a limited number of medical terms in each field, which is a clear limitation of the studies. In order to overcome this limitation, this study compared a total of 2,168 terms, not including repetitious terms, in South Korean and North Korean surgery textbooks; we then extracted and organized all the medical terms from a variety of fields used in the introduction and in specialized subjects of surgery, including general medical terms.

This comparative analysis of South Korean and North Korean medical terminologies revealed major differences in medical terminology. In North Korea, terms were more literal, directly explaining the meaning of the term in order to help the general public (not involved in the field of medicine) to more easily understands them [8]. This was more often observed in medical terms used for symptoms and signs for which it is necessary for doctors to question patients directly. For example, among medical terms for symptoms and signs, "pigarae" (pure Korean meaning blood sputum, a term used for hemoptysis), "geugi" (pure Korean meaning vomiting, or throwing up, a term used for nausea), and "ojumjatgi" (pure Korean meaning frequently urinating, a term used for frequent urination) were used in North Korea for the corresponding South Korean medical terms "gaekyeol" (Sino-Korean meaning hemoptysis), "guyeog" (SinoKorean meaning nausea), and "binnyo" (Sino-Korean meaning frequent urination), respectively.

However, the problem with such medical terminology is that it reduces the expertise of those in the field. For this reason, South Korea categorizes medical termin- 
ology into general terms and technical terms and uses the terms with flexibility according to the audience or readers [1]. However, there are only a few technical terms that have a corresponding general term in South Korea. More efforts are required to match a greater number of technical terms with general terms that are easier for the public to understand. These efforts will contribute to establishing a more reasonable medical terminology system.

The limitation of this study is that it was not possible to use the most recently revised North Korean terms because the latest North Korean surgery textbook available in South Korea is a medical book that was published in 2000 [6]. In addition, although the study analyzed medical terms from across diverse fields that were found in the introduction and specialized subjects of surgery, including general medical terms, a great number of these were terms related to surgery. Thus, additional studies are necessary for medical terms used in other subspecialties. Nevertheless, the study demonstrates, for the first time, the fact that the ratio of identical South Korean and North Korean medical terms related to surgery is less than half, indicating a necessity for greater efforts to reduce the discrepancy between South Korean and North Korean medical terminologies. In conclusion, this study showed that less than half of the medical terms related to surgery used in South Korea and North Korea are identical. It is expected that the prolonged division between South Korea and North Korea will only increase the discrepancy in the medical terminologies. Academic exchange between the two countries is necessary in order to reduce this discrepancy in preparation for reunification.

\section{ORCID:}

Keunyoung Hur: https://orcid.org/0000-0003-0928-951X;
Do-Eon Park: https://orcid.org/0000-0001-5562-0416; Heung-Kwon Oh: https://orcid.org/0000-0002-8066-2367; Hyun Hui Yang: https://orcid.org/0000-0003-1035-0277; Dayoung Ko: https://orcid.org/0000-0002-6090-1906; Min-Hyun Kim: https://orcid.org/0000-0002-9414-7817; Myung Jo Kim: https://orcid.org/0000-0003-2878-1227; Sung Il Kang: https://orcid.org/0000-0002-4751-5779; Duck-Woo Kim: https://orcid.org/0000-0001-9218-4676; Sung-Bum Kang: https://orcid.org/0000-0002-9574-5069 Acknowledgements: None.

Funding: This work was supported by the University research fund.

Conflicts of interest: : No potential conflict of interest relevant to this article was reported.

Author contributions: Conceptualization: KH, DEP, HKO, DK, MHK, MJK, SIK, DWK, SBK; data curation: KH, DEP, HKO, HHY, DK; investigation: KH, DEP, HKO, DK, MHK, MJK, SIK, DWK, SBK; writing-original draft preparation: $\mathrm{KH}, \mathrm{DEP}, \mathrm{HKO}, \mathrm{DK}, \mathrm{MHK}, \mathrm{MJK}$, SIK; and writing review and editing: KH, DEP, HKO, DK, MHK, MJK, SIK, DWK, SBK.

\section{References}

1. Chi JG. The actual conditions and problems of medical terms refinement. Saegugeosaenghwal. 201 1;21(2):105121.

2. Sohn SG. The development process of medical terminology in North Korea: focusing on surgical terminology. Paper presented at: Proceedings of the Round Table Discussion on Medical Terminology; January 22, 2014; Seoul, Korea. http://www.namok.org/. Accessed October 10, 2017.

3. Huh S. Comparison of medical terminology between North and South Korea: focusing on parasitology terminology. Asian Cult. 1995;(11):203-212. 
Keunyoung Hur, et al: South and North Korean differences in medical terminology

4. Kim WO, Kil HK, Kang JW, Kim KH. Comparison of anesthesiology related terminology between South and North Korea. Korean J Anesthesiol. 1996;30(1):31-40.

5. Korean Society of Surgery. Surgery. 2nd ed. Paju, Korea: Kunja Publication; 2017.

6. Gang PH. Surgery. Pyeongyang, North Korea: Compre- hensive Publisher of Science Encyclopedia; 2000.

7. Medical Terminology Practitioner of Korean Medical Association. English-Korean, Korean-English medical glossary. Anyang, Korea: Academia; 2009.

8. Suh CM. On the refining of technical terms in North Korea. Korean J Med Educ. 1996;8(1):33-52. 